\title{
A New Strain of Melon necrotic spot virus that Is Unable to Systemically Infect Cucumis melo
}

\author{
Takehiro Ohki, Isamu Sako, Ayami Kanda, Tomofumi Mochizuki, Yohachiro Honda, and Shinya Tsuda
}

First, third, fourth, fifth, and sixth authors: National Agricultural Research Center, 3-1-1 Kannondai, Tsukuba, Ibaraki 305-8666, Japan; and second author: Division of Farmland Policy Planning, 1-220, Higashimachi, Tottori, Tottori 680-8570, Japan.

Current address of fourth author: Graduate School of Life and Environmental Science, Osaka Prefecture University, Osaka 599-8531, Japan

Current address of fifth author: Musashino Seed Co., Ltd., 881, Ohata, Tsutiura, Ibaraki 300-4111, Japan.

Accepted for publication 30 July 2008.

\begin{abstract}
Ohki, T., Sako, I., Kanda, A., Mochizuki, T., Honda, Y., and Tsuda, S. 2008. A new strain of Melon necrotic spot virus that is unable to systemically infect Cucumis melo. Phytopathology 98:1165-1170.

We report a new strain of Melon necrotic spot virus (MNSV) that is unable to systemically infect Cucumis melo. A spherical virus (W-isolate), about $30 \mathrm{~nm}$ in diameter like a carmovirus, was isolated from watermelons with necrotic symptoms. The $\mathrm{W}$-isolate had little serological similarity to MNSV, and it did not cause any symptoms in six melon

of MNSV, and its p89 protein and coat protein (CP) showed 81.6 to $83.2 \%$ and 74.1 to $75.1 \%$ identity to those of MNSV, respectively. Analysis of protoplast showed that the $\mathrm{W}$-isolate replicated in melons at the single-cell level. Furthermore, chimeric clones carrying the CP of MNSV induced necrotic spots in melons. These results suggested that the absence of symptoms in melons was due to a lack of ability of the Wisolate to move from cell to cell. In view of these findings, we propose that the new isolate should be classified as a novel MNSV watermelon strain.
\end{abstract} cultivars susceptible to MNSV; however, the host range of the $\mathrm{W}$-isolate was limited exclusively to cucurbitaceous plants, and transmission by $O$. bornovanus was confirmed. Its genomic structure was identical to that
Additional keyword: moonflower.

case of Cucumber necrosis virus (CNV) in the genus Tombusvirus (28).

MNSV or related isolates have also been identified on cucumber (C. sativus L.) $(2,3,31)$ and watermelon (Citrullus lanatus (Thunb.) Matsum. et Nakai) $(1,2)$ in Europe. The cucumber isolates have a similar host range and serological reactions to those of the MNSV melon isolate. However, the watermelon isolates developed only small necrotic spots on melons and cause local infections on Gomphrena globosa L., Nicotiana benthamiana Domin, and N. clevelandii Gray, unlike MNSV melon isolates (1). In addition, agar gel-diffusion and cross-absorption tests revealed only a weak serological relationship between the watermelon isolate and the MNSV melon isolate (1). Avgelis proposed in 1989 that the watermelon isolate be considered as a serologically distinct strain of MNSV, though he pointed out that the difference in serological properties raised the possibility that the isolate should be considered a new virus (1).

In Japan, viral symptoms have also been observed on watermelon grafted onto moonflower (Lagenaria siceraria (Molina) Standl. var. hispida (Thunb.) H. Hara) rootstock. In a preliminary examination, we observed a spherical virus of about $30 \mathrm{~nm}$ diameter from diseased plants, but it was hardly detected with MNSV antibody, suggesting that it was an identical or similar isolate to the watermelon isolate previously described by Avgelis $(1,2)$. However, the isolate did not induce any symptoms on Japanese melon cultivars, which raised the question of whether it was MNSV. The species demarcation criteria in the genus Carmovirus consist of host reactions, serological relationships, the possibility of fungal transmission, and amino acid sequence identity of less than $41 \%$ between $\mathrm{CP}$ and $52 \%$ between polymerases (21). Here we present a detailed characterization of the watermelon isolate in Japan with respect to host range, genomic sequence, and fungal transmission in order to clarify its classification. In addition, we have determined the ORF that is needed for forming

doi:10.1094/PHYTO-98-11-1165

(C) 2008 The American Phytopathological Society 
necrotic spots on melon using chimeras between the watermelon and melon isolates.

\section{MATERIALS AND METHODS}

Viral isolates, purification, and antibody production. The watermelon isolate (designated the $\mathrm{W}$-isolate) was obtained from diseased fruits grown in Tottori Prefecture, Japan, by successive single-lesion isolation on a moonflower. MNSV-chi was used as a standard melon isolate in Japan $(17,18,24)$. The $\mathrm{W}$-isolate was observed by electron microscopy using the clarified viral concentrate procedure (7).

The $\mathrm{W}$-isolate was purified according to the method described by Hibi and Furuki (14). Rabbits were immunized with purified W-isolate, and the immunoglobulin fraction was isolated with a MabTrap kit (GE Healthcare Biosciences, Piscataway, NJ).

Host range and symptomatology. The host range and symptomatology against 12 species from six families were examined by mechanical inoculation. Plants were inoculated with infected leaf sap from leaves ground in 10 times their volume of $50 \mathrm{mM}$ phosphate buffer ( $\mathrm{pH} \mathrm{7.0)}$ and grown at 24 to $27^{\circ} \mathrm{C}$ in a greenhouse for 3 weeks. Infection was checked by reinoculation of watermelon or melon 3 weeks after inoculation.

Propagation of $O$. bornovanus and the virus transmission test. Single-sporangium isolation was conducted using the procedures described by Lin et al. (22). Roots dipped in ice water for $15 \mathrm{~min}$ were cut roughly in distilled water, and suspensions including root pieces were dotted on chilled agar plates. Single sporangia were cut off with agar under a phase microscope and inoculated for propagation on plants. Plants were maintained in commercial nursery soil (Kureha engei baido; JA, Japan) with $0.5 \%$ calcium hydroxide added, at 25 to $30^{\circ} \mathrm{C}$ under a $16-\mathrm{h}$ photoperiod in a growth chamber.

For transmission tests, zoospores (final concentration $3 \times 10^{5}$ cells $/ \mathrm{ml}$ ) were mixed with the supernatant of infected leaf sap (final concentration $\times 25$ dilution). After the mixture sat for $15 \mathrm{~min}$

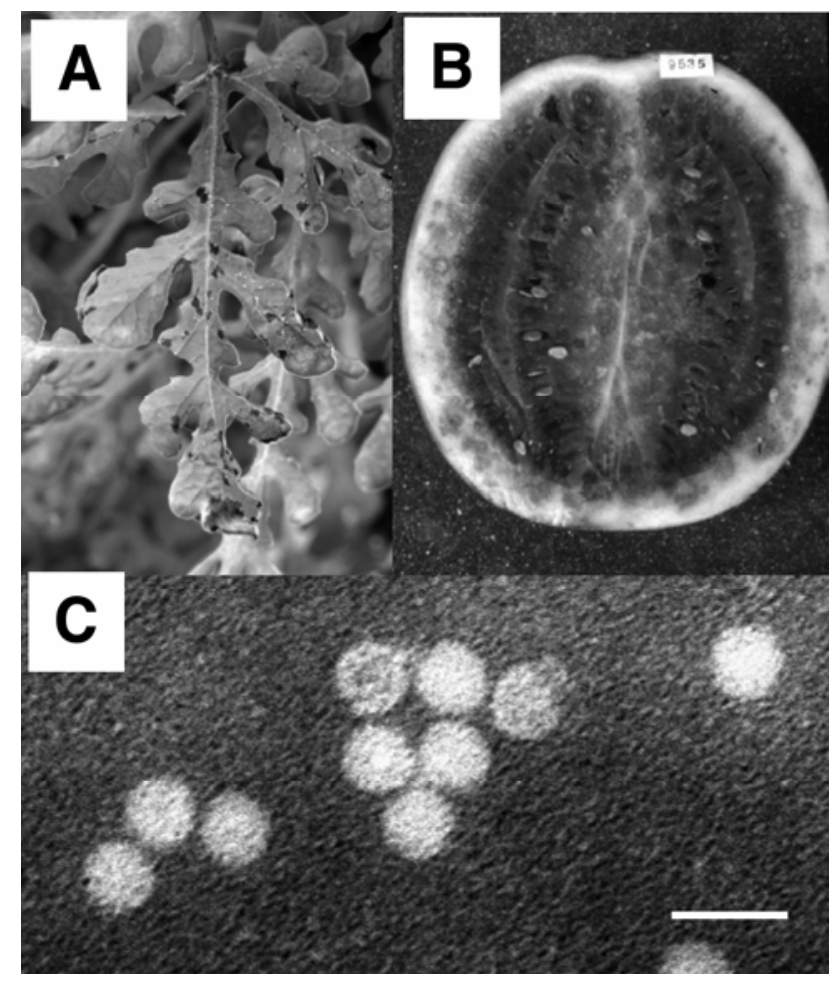

Fig. 1. Necrotic symptoms on watermelon observed in the field, and an electron micrograph of the W-isolate. A, Necrosis on the leaves. B, Necrotic symptoms on the fruit. $\mathbf{C}, \mathrm{W}$-isolate stained with $2 \%$ phosphotungstic acid. Scale bar $=50 \mathrm{~nm}$. at room temperature, $1 \mathrm{ml}$ of the suspension was poured onto the roots of watermelon or moonflower plants grown in vermiculite with Hoagland basal medium (Sigma, St. Louis, MO), $\mathrm{pH} 7.5$, at $27^{\circ} \mathrm{C}$. One week later, virus infection of the roots was assessed by an indirect enzyme-linked immunosorbent assay (ELISA) (30) using the antibody against the $\mathrm{W}$-isolate. Absorbance values at $405 \mathrm{~nm}$ that were threefold or more higher than the negative control were judged to be positive.

Sequencing. Total RNA was isolated from infected leaves with an RNeasy plant RNA isolation kit (Qiagen, Valencia, CA). cDNAs were prepared by reverse transcription with ReveTra Ace (Toyobo, Tokyo, Japan), and the products were amplified by polymerase chain reaction (PCR) with KOD plus polymerase (Toyobo, Japan). To amplify the genomic RNA of the W-isolate, we used about 30 primers designed for sequencing MNSV-chi. By trying random combinations of these primers, we found three pairs that amplified three fragments covering most of the sequence. The primers were as follows: MF1 (5'-GGGGAAGAAGTGGTTGAGCA-3'), MR1 (5'-AGGGATAAGCCACACAAGCC-3'), MF2 (5'-CCGACGCTCTTAAATGGGAA-3'), MR2 (5'TCCCTATGAACTATCTTCAC-3'), MF3 (5'-GGGAAATCCTAGAATACAGCC-3'), and MR3 (5'-AGCCAGACCGCACTACACAC-3'). The $5^{\prime}$ and $3^{\prime}$ terminal sequences of the $\mathrm{W}$-isolate were determined by rapid amplification of cDNA ends-PCR using anchor primers (32). The fragments obtained were directly sequenced with a 3100 genetic analyzer (Applied Biosystems, Foster City, CA). Pairwise comparisons of putative amino acid sequences were carried out using Genetyx software (Genetyx Corp., Tokyo, Japan).

Construction of infectious clones, RNA transcription in vitro, and tissue immunoblotting assay. A full-length cDNA of the $\mathrm{W}$-isolate was amplified by the primer pair Clone-F (aaaggtacc taatacgactcactatagGGAAATCTCTAGCCGATTC [5' ends 19 nucleotides (capitalized) with a KpnI site (italicized) and T7 promoter (underlined)]) and Clone-R (tttctgcagcttaaGGGCGGGGAGACCCGATAAG [3' ends 21 nucleotides (capitalized) with Bst98I (italicized) and a PstI site (underlined)]), digested with KpnI and PstI, and cloned into pUC19 (designated pUCW25). The full-length cDNA of MNSV-chi was previously cloned into pBluscripts SKII (pTMNW1) (24). Five chimeras between the $\mathrm{W}$-isolate and MNSV-chi (designated WM1 5) were generated by a chimeric PCR procedure (15) and cloned into pUC19. These constructs were confirmed by sequencing. RNA transcripts were synthesized in vitro from $1 \mu \mathrm{g}$ of NgoMIV(pTMNW1) or Bst98I-(other clones) digested linear plasmid DNA using the T7 RiboMAX Express large-scale RNA production system (Promega Corp., Madison, WI) according to the manufacturer's manual. A 10- $\mu$ l sample of the reaction mixtures diluted 1:20 with distilled water was rubbed with carborundum on the cotyledons of the test plants, and they were grown at 24 to $27^{\circ} \mathrm{C}$ in a greenhouse. The localization of viruses in inoculated leaves was examined by a tissue immunoblotting assay (TIBA) as previously described (18).

Preparation of melon protoplasts and northern blot analysis. After washing with $70 \%$ ethanol and distilled water, cotyledons of 1-week-old melon seedlings (Cucumis melo L. cv. Miyabi) were sliced into 1- to 2-mm strips with a razor blade. Thereafter, the preparation of protoplasts and their inoculation with RNA transcripts was carried out as previously described (18). The inoculated protoplasts were incubated at $25^{\circ} \mathrm{C}$ for $24 \mathrm{~h}$ in the dark, and then total RNAs from protoplasts were extracted with TRIzol LS (Invitrogen, Carlsbad, CA) according to the manufacturer's instructions.

For synthesis of a riboprobe, the $\mathrm{CP}$ gene fragments were cloned into pCR-Blunt II-TOPO (Invitrogen), designated pWCP for the $\mathrm{W}$-isolate and $\mathrm{pMCP}$ for MNSV-chi, respectively. Each riboprobe was produced in vitro with the DIG RNA labeling mix (Roche Diagnostics, Penzberg, Germany) and the T7 RiboMAX 
large-scale RNA production system (Promega). The sensitivity of the riboprobe against the $\mathrm{W}$-isolate was 5.2 times as high as that against MNSV-chi (data not shown), although each riboprobe was used at $100 \mathrm{ng} / \mathrm{ml}$. Total RNAs were separated on a $1.5 \%$ denatured agarose gel, transferred to Hybond-N+ membrane (GE Healthcare Bio-sciences), and cross-linked with UV illumination at $120 \mathrm{~mJ} / \mathrm{cm}^{2}$ using a Funa-UV-Crosslinker (Funakoshi, Tokyo, Japan). Prehybridization and hybridization were carried out in UltraHyb (Ambion, Austin, TX) at $68^{\circ} \mathrm{C}$ for $1 \mathrm{~h}$ and overnight, respectively. The chemiluminescence signals were detected with a VersaDoc 5000 (Bio-Rad Laboratories, Inc., Hercules, CA). To compare the accumulation of W-isolate and MNSV-chi, the band intensities were quantified by ImageJ (ImageJ is available online from the National Institutes of Health) and normalized with $28 \mathrm{~S}$ ribosomal RNA (rRNA).

\section{RESULTS}

Host range and symptomatology of the $W$-isolate. Watermelons infected in the field had been showing necrotic symptoms on veins and leaves, and sometimes on the petiole and cirrus (Fig. 1A). The fruits had yellowish brown necrosis, and the pericarp and flesh were watery and hollow (Fig. 1B). Electron microscopy revealed spherical virus-like particles, approximately $30 \mathrm{~nm}$ in diameter, which were similar to MNSV and other carmoviruses (Fig. 1C). However, the commercial double-antibody sandwichELISA kit for MNSV (Japan Plant Protection Association, Japan) barely reacted with the sap of the diseased watermelons (data not shown).

First, we investigated the host range and symptomatology of the $\mathrm{W}$-isolate, comparing them to those of MNSV-chi (Table 1). The host range of the $\mathrm{W}$-isolate is limited exclusively to cucurbi- taceous plants. However, the $\mathrm{W}$-isolate did not infect six melon cultivars susceptible to MNSV-chi. Only two varieties of melon, C. melo var. makuwa Makino and var. conomon (Thunb.) Makino, were infected locally. Systemic infection to watermelon by the Wisolate rarely occurred. In moonflowers, both viruses were restricted to inoculated leaves, but the necrotic spots caused by the $\mathrm{W}$-isolate developed more rapidly and grew larger. The infection to G. globosa, N. benthamiana, and three resistant cultivars of melon that probably carry the recessive MNSV resistance gene, $n s v$ (9), was not confirmed.

We tried to reproduce necrotic symptoms on watermelon fruits in the field. The symptoms appeared on fruits only when the $\mathrm{W}$ isolate was inoculated into a watermelon grafted onto a moonflower (data not shown).

Transmission by $\boldsymbol{O}$. bornovanus. The two $O$. bornovanus isolates used in this experiment are described in Table 2. Both isolates formed resting spores with a smooth cell wall, and zoospores with an elliptical head and flagellum, corresponding to the descriptions of Campbell and Sim (4). The Nw1 isolate propagated well in squash (Cucurbita maxima Duchesne), whereas the Y1 isolate did well in oriental melon (C. melo L. var. makuwa). Both could infect watermelon and moonflower.

A transmission test was conducted for each combination of virus and vector (Table 3 ). The $\mathrm{W}$-isolate was effectively transmitted to watermelon and moonflower by the Nw1 isolate from a watermelon field, but it was barely transmitted by the Y1 isolate from a melon field. On the other hand, MNSV-chi showed the opposite fungal transmission efficiency. The W-isolate and MSNVchi showed different compatibility with each $O$. bornovanus isolate.

Sequencing and comparison of deduced amino acid sequences. We amplified cDNA corresponding to the genomic

TABLE 1 . Host range and symptomatology of W-isolate and Melon necrotic spot virus (MNSV)-chi

\begin{tabular}{|c|c|c|c|c|c|}
\hline \multirow[b]{3}{*}{ Family and plant species } & \multirow[b]{3}{*}{ Cultivar } & \multicolumn{4}{|c|}{ Symptoms $^{\mathrm{a}}$} \\
\hline & & \multicolumn{2}{|c|}{ W-isolate } & \multicolumn{2}{|c|}{ MNSV-chi } \\
\hline & & Inoculated leaves & Upper leaves & Inoculated leaves & Upper leaves \\
\hline \multicolumn{6}{|l|}{ Aizoaceae } \\
\hline Tetragonia tetragonoides & & - & - & - & - \\
\hline \multicolumn{6}{|l|}{ Amaranthaceae } \\
\hline Gomphrena globosa & & - & - & - & - \\
\hline \multicolumn{6}{|l|}{ Chenopodiaceae } \\
\hline Chenopodium amaranticolor & & - & - & - & - \\
\hline \multicolumn{6}{|l|}{ Cucurbitaceae } \\
\hline Benincasa hispida & Jukanme daimaru tougan & - & - & - & - \\
\hline Citrullus lanatus & Ibuki & NS & $(\mathrm{N}, \mathrm{NS})$ & NS & - \\
\hline \multirow[t]{9}{*}{ Cucumis melo } & Andesu melon & - & - & NS & (NS) \\
\hline & Ãrusunaito & - & - & NS & (NS) \\
\hline & Ãrususeinu natsukei 2 & - & - & NS & $(\mathrm{NS})$ \\
\hline & Benechia & - & - & NS & (NS) \\
\hline & Miyabi & - & - & NS & (NS) \\
\hline & Mone & - & - & NS & (NS) \\
\hline & Einea $^{\mathrm{b}}$ & - & - & - & - \\
\hline & Ãnesto ${ }^{b}$ & - & - & - & - \\
\hline & Fuyu no sonata ${ }^{b}$ & - & - & - & - \\
\hline C. melo var. makuwa & Kintarou & sNS & - & NS & - \\
\hline C. melo var. conomon & Sanuki shirouri & sNS & - & NS & - \\
\hline C. sativus & Kaga aonaga kyuuri & $\mathrm{CS}$ & - & CS & - \\
\hline Cucurbita maxima & Ebisu & - & - & - & - \\
\hline \multirow[t]{3}{*}{ Lagenaria siceraria var. hispida } & Jyukanme daimaru kanpyou & NS & - & sNS & - \\
\hline & Don $\mathrm{K}$ & NS & - & sNS & - \\
\hline & Kachidoki & NS & - & sNS & - \\
\hline \multicolumn{6}{|l|}{ Leguminosae } \\
\hline Phaseolus vulgaris & & - & - & - & - \\
\hline \multicolumn{6}{|l|}{ Solanaceae } \\
\hline Nicotiana benthamiana & & - & - & - & - \\
\hline N. tabacum & Xanti nc & - & - & - & - \\
\hline
\end{tabular}

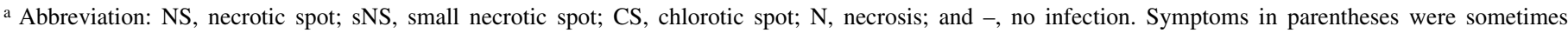
observed.

b A resistant cultivar for MNSV 


\begin{tabular}{|c|c|c|c|c|c|c|c|}
\hline \multirow[b]{2}{*}{ Isolates } & \multirow[b]{2}{*}{ Source of soil } & \multirow[b]{2}{*}{ Bait plant ${ }^{\mathrm{a}}$} & \multirow[b]{2}{*}{ Propagation plant } & \multicolumn{4}{|c|}{ Host specificity ${ }^{b}$} \\
\hline & & & & Watermelon & Moonflower & Melon & Squash \\
\hline Nw1 & Watermelon field in Nagasaki, Japan & Watermelon & Squash & ++ & +++ & - & +++ \\
\hline Y1 & Melon field in Yamaguchi, Japan & Oriental melon & Oriental melon & ++ & ++ & +++ & - \\
\hline
\end{tabular}

a Plants used for isolation of $O$. bornovanus from soil.

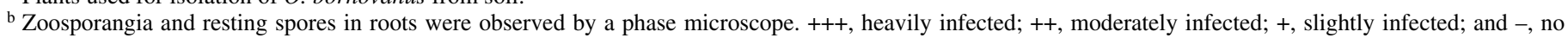
zoosporangia and resting spores in roots.

TABLE 3. Transmission of W-isolate and Melon necrotic spot virus (MNSV)chi by Olpidium bornovanus

\begin{tabular}{llcc}
\hline & & \multicolumn{2}{c}{ Virus transmission Olpidium $^{\mathrm{a}}$} \\
\cline { 3 - 4 } Virus & O. bornovanus & Watermelon & Moonflower \\
\hline W-isolate & NW1 isolate & $12 / 12$ & $12 / 12$ \\
& Y1 isolate & $2 / 12$ & $0 / 12$ \\
MNSV-chi & - & $0 / 16$ & $0 / 14$ \\
& NW1 isolate & $5 / 15$ & n.t. \\
& Y1 isolate & $14 / 15$ & n.t. \\
& - & $0 / 11$ & n.t \\
& NW1 isolate & $0 / 15$ & $0 / 15$ \\
& Y1 isolate & $0 / 10$ & n.t.
\end{tabular}

a The number of virus-infected plants/tested plants. The results show the total of four to five experiments, respectively.

b Not tested.

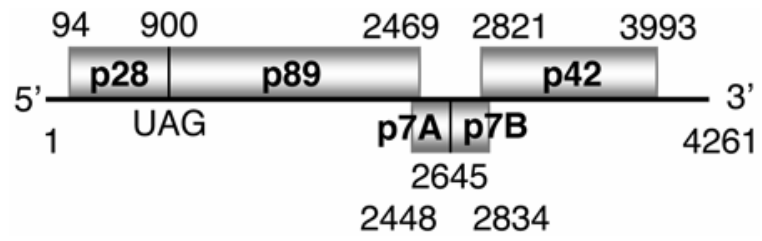

Fig. 2. Schematic representation of the $\mathrm{W}$-isolate genomic organization. The five predicted open reading frames are boxed. Numbers indicate the positions of nucleotide bases. UAG indicates the amber stop codon for read-through.

RNA of the W-isolate by PCR with the primers designed for MNSV-chi and determined its full-length sequence. The genomic RNA of the W-isolate was 4,261 nucleotides long and encoded five putative ORFs (accession no. AB232925) (Fig. 2). This genomic structure was identical to that of the MNSV isolates previously reported $(25,27)$ but was slightly different from that of other carmoviruses in the size of ORFs. The predicted amino acid sequence of the $\mathrm{W}$-isolate was compared with the corresponding ORFs of six MNSV isolates from melon (Table 4). On the whole, the W-isolate showed a high level of identity to the MNSV isolates. Although the ORFs of p7A, p7B, and p89 shared more than $80 \%$ identity, the p29 and CP ORFs only showed 68.7 to $69.4 \%$ and 74.1 to $75.1 \%$ identity, respectively. More than $90 \%$ identity was shared between the five ORFs of the six MNSV melon isolates (data not shown).

Accumulation of genomic RNA in melon protoplasts. The transcripts synthesized from the infectious cDNA clone, pUCW25, were identical to the $\mathrm{W}$-isolate genomic sequence. They induced the same symptoms as the parent isolate in watermelon, melon, and moonflower.

In Northern analysis, three major bands representing one genomic and two subgenomic RNAs were detected, when transcripts of the W-isolate or MNSV-chi were inoculated into melon protoplasts (Fig. 3). The $\mathrm{W}$-isolate was able to replicate on melon at the single-cell level, though it caused no symptoms in inoculated leaves. When the accumulation of genomic RNA was compared in consideration of the riboprobe sensitivity, the rate of $\mathrm{W}$ isolate to MNSV-chi was calculated as $0.30 \pm 0.08$ (average $\pm \mathrm{SE}$, $\mathrm{n}=4)$.
TABLE 4. Comparison of the deduced amino acid sequence with the corresponding open reading frames of other Melon necrotic spot virus (MNSV) melon isolates

\begin{tabular}{lccccc}
\hline & \multicolumn{5}{c}{ Amino acid sequence identity (\%) } \\
\cline { 2 - 6 } MNSV isolate & p29 & p89 & p7A & p7B & CP \\
\hline chi & 69.4 & 82.8 & 86.2 & 82.0 & 74.6 \\
Dutch & 69.4 & 82.7 & 89.2 & 85.2 & 75.1 \\
NK & 68.7 & 82.2 & 86.2 & 85.2 & 74.9 \\
NH & 69.0 & 81.6 & 87.7 & 85.2 & 74.1 \\
YS & 69.8 & 82.9 & 89.2 & 85.2 & 74.4 \\
KS & 69.8 & 83.2 & 86.2 & 86.9 & 75.1 \\
\hline
\end{tabular}

a Accession numbers: MNSV-chi (AB250684), MNSV-Dutch (M29671), MNSV-NK (AB044292), MNSV-NH (AB044291), MNSV-YS (AB189944), and MNSV-KS (AB189943)

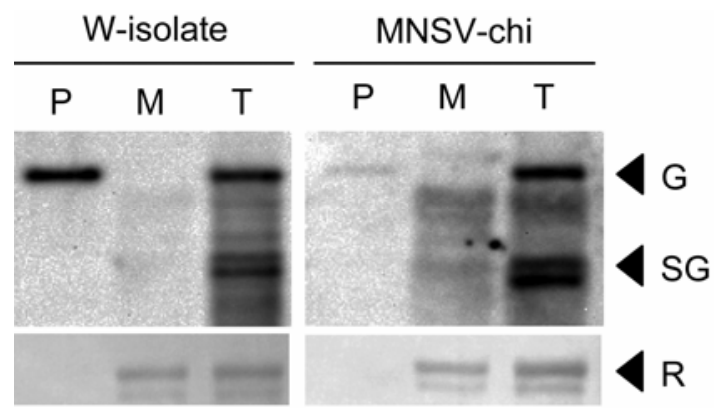

Fig. 3. Accumulation of $\mathrm{W}$-isolate and Melon necrotic spot virus (MNSV)-chi in melon protoplasts. Each lane contains $10 \mathrm{ng}$ of transcript RNA (P, positive control) or $5.0 \mu \mathrm{g}$ of total RNA extracted from melon protoplasts (M, mock inoculation; $\mathrm{T}$, transcripts inoculation). The $28 \mathrm{~s}$ rRNAs were stained with $0.02 \%$ methylene blue solution. The positions of genomic RNA (G), subgenomic RNA (SG), and 28S rRNAs (R) are indicated on the right of the panel.

Analysis of the viral factor controlling infection to melons using chimeric clones. We constructed five chimeras between the $\mathrm{W}$-isolate and MNSV-chi to examine why the isolate did not develop necrotic spots on inoculated melon leaves (Fig. 4). All of the five chimeric clones had infectivity to watermelon (Fig. 4). On melon, the W-isolate developed no symptoms and was not detected by TIBA (Figs. 4 and 5). By contrast, the WM2 and WM4 chimeric clones with the CP ORF of MNSV-chi formed necrotic spots on melon (Figs. 4 and 5). However, the size of these necrotic spots was smaller than those of MNSV-chi (Fig. 5), and they did not spread to the whole melon, systemically (data not shown). Infection of WM3 chimeric clone with only p7A and p7B replaced was not confirmed by TIBA (data not shown). From these results, we conclude that the $\mathrm{W}$-isolate requires the $\mathrm{CP}$ of MNSV-chi to form necrotic spots on melon.

\section{DISCUSSION}

The host range of the $\mathrm{W}$-isolate was limited exclusively to cucurbitaceous plants (Table 1). Sequence analysis of the Wisolate showed that it had an identical genomic structure (Fig. 2) and a high level of identity (Table 4) to the MNSV melon isolates. Transmission by $O$. bornovanus was also confirmed (Table 3 ). 


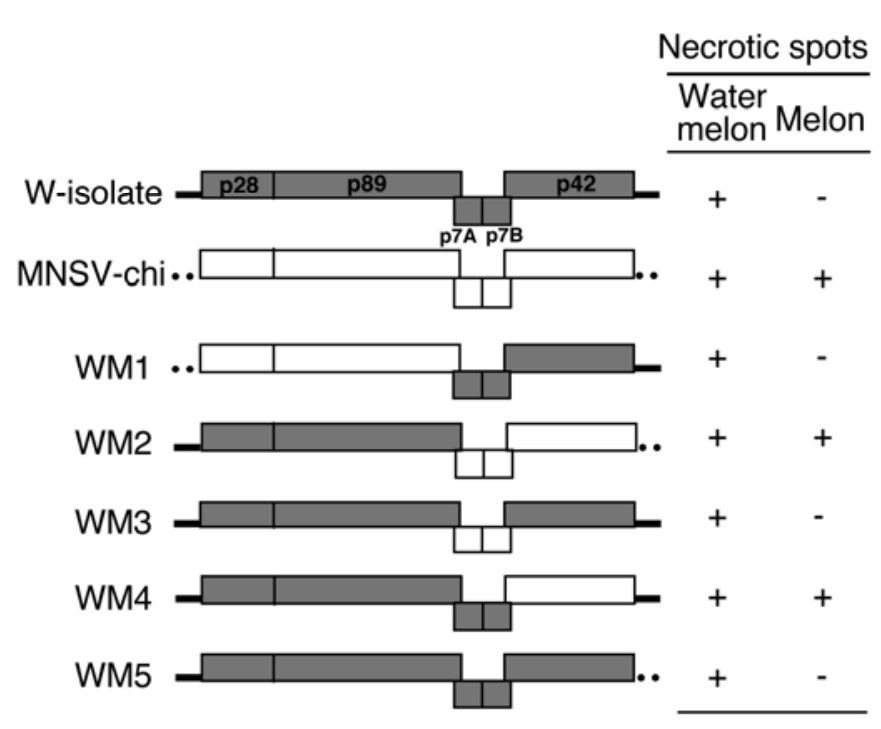

Fig. 4. Schematic representation of the chimeras between the W-isolate and Melon necrotic spot virus (MNSV)-chi, and the formation of necrotic spots on the inoculated leaves of watermelon and melon. Solid lines and boxes show the genomic sequence of the W-isolate, and dotted lines and outline boxes show the genomic sequence of MNSV-chi. + , formation of necrotic spot; and - , no symptoms.

From these results, it is not doubtful that the $\mathrm{W}$-isolate is related to MNSV. On the other hand, the W-isolate did not induce any symptoms on Japanese melon cultivars. However, we exactly confirmed the accumulation of $\mathrm{W}$-isolate RNAs in melon protoplast (Fig. 3), indicating that the W-isolate can infect melon but not to move from cell to cell in melon. Therefore, we conclude that there is no big difference between the host range of the $\mathrm{W}$ isolate and MNSV-chi. Furthermore, the species criteria for amino acid sequence identity (21) also failed to support the existence of a distinct species (Table 4). In view of these findings, the Wisolate should belong to MNSV, although the genomic sequence of the W-isolate clearly distinguish it from that of MNSV melon isolate. Consequently, we propose that the $\mathrm{W}$-isolate be classified as a new MNSV watermelon strain. We suggest that the watermelon isolate described by Avgelis $(1,2)$ is similar to our isolate, although no sequence information on it is available.

Transmission tests have shown that the W-isolate and MNSVchi are highly compatible with each $O$. bornovanus isolate from the corresponding field soils. Campbell and Sim divided $O$. bornovanus isolates into three host-specific strains: cucumber, melon, and squash (4). The three strains were all able to transmit MNSV to watermelon, and no difference in transmission efficiency was observed among the strains (5). The Nw1 and Y1 isolates might correspond to their squash and melon strains, respectively; however, to determine whether this is the case it will be necessary to investigate their host plants and other ecological characters further.

The Nw1 and Y1 isolates propagated in watermelon at a similar level (Table 2), whereas the transmission efficiencies of the $\mathrm{W}$ isolate and MNSV-chi differed (Table 3). This suggests that the difference of transmission efficiency can be attributed to compatibility between vector and virus, not between vector and host plant. The CPs of carmoviruses and tombusviruses are known to play important roles in fungal transmission. For example, a mutation of $\mathrm{CNV} \mathrm{CP}$ decreased binding of the virus particles to the zoospore surface and led to a decline in the rate of transmission (16). A point mutant of MNSV CP caused similar results (24). As shown in Table 4, the CP of the W-isolate and MNSV melon isolates showed about $75 \%$ identity. Therefore, transmission efficiency appears to depend on the $\mathrm{CP}$ sequence and the ability to be absorbed by zoospores.



Fig. 5. Formation of necrotic spots and detection of viruses on inoculated leaves by tissue immunoblotting assay. Watermelon and melon cotyledons were sampled at 3 and 5 days postinoculation, respectively. The white boxes show enlargements of small necrotic spots induced by WM2 and WM4.

Northern analysis in melon protoplasts indicated that cell-tocell movement of the $\mathrm{W}$-isolate on melon was blocked. The accumulation of $\mathrm{W}$-isolate was lower than that of MNSV-chi, but the difference in accumulation cannot explain the lack of symptoms in melon. WM3 with only p7A and p7B switched did not expand on inoculated leaves of melon, although the two p7 are indispensable for local movement in MNSV (11). On the other hand, as shown in Figure 5, cell-to-cell movement of the $\mathrm{W}$ isolate on melon required the $\mathrm{CP}$ of MNSV-chi. It has been reported that the $\mathrm{CP}$ of carmoviruses is involved in systemic movement (8) but that it is not necessary for cell-to-cell movement (29), except for Turnip crinkle virus in N. benthamiana (13). In MNSV, Genovés et al. (11) reported that MNSV CP promotes local spreading in addition to systemic movement, since the absence of CP reduces infection focus size without influencing the accumulation of viral RNAs at the single-cell level. In addition, they pointed out that MNSV CP had a weak ability to suppress RNA silencing, which might lead to enhanced cell-tocell movement. Considering these findings, we believe that $\mathrm{W}$ isolate $\mathrm{CP}$ is not able to support cell-to-cell movement in melon, resulting in the absence of local and systemic spread of the virus.

The W-isolate has sporadically occurred in several regions in Japan, and in each case the isolates had almost the same genomic sequence as the $\mathrm{W}$-isolate in the present study (data not shown). This strongly suggests that the $\mathrm{W}$-isolate spreads through seeds. In melon, the seed transmission of MNSV at a very low rate has been reported (6). It will be necessary to investigate the seed transmission of the $\mathrm{W}$-isolate in watermelon and moonflower.

\section{LITERATURE CITED}

1. Avgelis, A. D. 1989. Watermelon necrosis caused by a strain of melon necrotic spot virus. Plant Pathol. 38:618-622.

2. Avgelis, A. D. 1990. Melon necrotic spot virus in plastic houses on the island of Crete. Acta Hortic. 287:349-354.

3. Bos, L., Van Dorst, H. J. M., Huttinga, H., and Matt, D. Z. 1984. Further characterization of melon necrotic spot virus causing severe disease in glasshouse cucumbers in the Netherlands and its control. Neth. J. Plant Pathol. 90:55-69.

4. Campbell, R. N., and Sim, S. T. 1994. Host specificity and nomenclature of Olpidium bornovanus (=Olpidium radicale) and comparisons to Olpidium brassicae. Can. J. Bot. 74:1136-1143.

5. Campbell, R. N., Sim, S. T., and Lecoq, H. 1995. Virus transmission by host-specific strains of Olpidium bornovanus and Olpidium brassicae. Eur. J. Plant Pathol. 101:273-282.

6. Campbell, R. N., Wipf-Scheibel, C., and Lecoq, H. 1996. Vector-assisted seed transmission of Melon necrotic spot virus in melon. Phytopathology 86:1294-1298. 
7. Christie, S. R., Purcifull, D. E., Crawford, W. E., and Ahmed, N. A. 1987. Electron microscopy of negatively stained clarified viral concentrates obtained from small tissue samples with appendices on negative staining techniques. Bull. Agric. Exp. Stn. Univ. Florida 872:45.

8. Cohen, Y., Gisel, A., and Zambryski, P. C. 2000. Cell-to-cell and systemic movement of recombinant green fluorescent protein-tagged Turnip crinkle viruses. Virology 273:258-266.

9. Coudriet, D. L., Kishaba, A. N., and Bohn, G. W. 1981. Inheritance of resistance to Muskmelon necrotic spot virus in a melon aphid-resistant breeding line of muskmelon. J. Am. Soc. Hortic. Sci. 160:789-791.

10. Furuki, I. 1981. Epidemiological studies on melon necrotic spot. Tech. Bull. Shizuoka Agric. Exp. Stn. 14:1-94.

11. Genovés, A., Navarro, J. A., and Pallás, V. 2006. Functional analysis of the five melon necrotic spot virus genome-encoded proteins. J. Gen. Virol. $87: 2371-2380$.

12. Gonzalez-Garza, R., Gumpf, D. J., Kishaba, A. N., and Bohn, G. W. 1979. Identification, seed transmission, and host range pathogenicity of a California isolate of Melon necrotic spot virus. Phytopathology 69:340-345.

13. Hacker, D. L., Petty, I. T. D., Wei, N., and Morris, T. J. 1992. Turnip crinkle virus genes required for RNA replication and virus movement. Virology 186:1-8.

14. Hibi, T., and Furuki, I. 1985. Melon necrotic spot virus. Descriptions of Plant Virus, No. 302. Published online by The Association of Applied Biologists, Warwick, UK.

15. Horton, R. M., Hunt, H. D., Ho, S. N., Pullen, J. K., and Pease, L. R. 1989. Engineering hybrid genes without the use of restriction enzymes: Gene splicing by overlap extension. Gene 77:61-68.

16. Kakani, K., Sgro, J.-Y., and Rochon, D. 2001. Identification of specific Cucumber necrosis virus coat protein amino acids affecting fungus transmission and zoospore attachment. J. Virol. 75:5576-5583.

17. Kido, K., Matsuo, K., Mochizuki, T., Tanaka, C., Kubota, K., Ohki, T., and Tsuda, S. 2008. Functional degeneration of the resistance gene nsv against Melon necrotic spot virus at low temperature. Eur. J. Plant Pathol. 121:189-194.

18. Kido, K., Tanaka, C., Mochizuki, T., Kubota, K., Ohki, T., Ohnishi, J., Knight, L. M., and Tsuda, S. 2008. High temperatures activate local viral multiplication and cell-to-cell movement of Melon necrotic spot virus, but restrict expression of systemic symptoms. Phytopathology 98:181-186.

19. Kishi, K. 1966. Necrotic spot of melon, a new virus disease. Ann. Phytopathol. Soc. Jpn. 32:138-144.

20. Kubo, C., Nakazono-Nagaoka, E., Hagiwara, K., Kajihara, H., Takeuchi, S., Matsuo, K., Ichiki, T. U., and Omura, T. 2005. New severe strains of
Melon necrotic spot virus: Symptomatology and sequencing. Plant Pathol. 54:615-620.

21. Lommel, S. A., Martelli, G. P., Rubino, L., and Russo, M. 2005 Carmovirus. Pages 922-926 in: Virus Taxonomy. Eighth Report of the International Committee on Taxonomy of Viruses. C. M. Fauquet, M. A. Mayo, J. Maniloff, U. Desselberger, and L. A. Ball, eds. Elsevier/ Academic Press, San Diego, CA.

22. Lin, M. T., Campbell, R. N., Smith, P. R., and Temmink, J. H. M. 1970. Lettuce big-vein virus transmission by single-sporangium isolates of Olpidium brassicae. Phytopathology 60:1630-1634.

23. Matsuo, K., Kameya-Iwaki, M., and Ota, T. 1991. Two new strains of Melon necrotic spot virus. Ann. Phytopathol. Soc. Jpn. 57:558-567.

24. Mochizuki, T., Ohnisi, J., Ohki, T., Kanda, A., and Tsuda, S. 2008. Amino-acid substitution in the coat protein of Melon necrotic spot virus causes loss of binding to the surface of Olpidium bornovanus zoospores. J. Gen. Plant Pathol. 74:176-181.

25. Ohshima, K., Ando, T., Motomura, N., Matsuo, K., and Sako, N. 2000. Comparative study on genomes of two Japanese melon necrotic spot virus isolates. Acta Virol. 44:309-314.

26. Riviere, C. J., Pot, J., Tremaine, J. H., and Rochon, D. M. 1989. Coat protein of melon necrotic spot carmovirus is more similar to those of tombusvirus than those of carmoviruses. J. Gen. Virol. 70:3033-3042.

27. Riviere, C. J., and Rochon, D. M. 1990. Nucleotide sequence and genomic organization of melon necrotic spot virus. J. Gen. Virol. 71:1887-1896

28. Rochon, D., Kakani, K., Robbins, M., and Reade, R. 2004. Molecular aspects of plant virus transmission by Olpidium and Plasmodiophorid vectors. Annu. Rev. Phytopathol. 42:211-241.

29. Scholthof, H. B. 2005. Plant virus transport: Motions of functional equivalence. Trends Plant Sci. 10:376-382.

30. Suzuki, N., Shirako, Y., and Ehara, Y. 1990. A simple method for elimination of non-specific reactions in non-precoated indirect and electroblot enzyme-linked immunosorbent assay procedures used for detection of Zucchini yellow mosaic virus. Ann. Phytopathol. Soc. Jpn. 56:337-341.

31. Tomlinson, J. A., and Thomas, B. J. 1986. Studies on melon necrotic spot virus disease of cucumber and on the control of the fungus vector (Olpidium radicale). Ann. Appl. Biol. 108:71-80.

32. Weng, Z., and Xiong, Z. 1995. A method for accurate determination of terminal sequences of viral genomic RNA. Genome Res. 5:202-207.

33. Yoshida, K., Goto, T., Nemoto, M., and Tsuchizaki, T. 1980. Five viruses isolated from melon (Cucumis melo L.) in Hokkaido. Ann. Phytopathol. Soc. Jpn. 46:339-348. 